\title{
The pain and pleasure of roller derby: Thinking through affect and subjectification
}

\section{Words 8702}

\begin{abstract}
:
Writing about pain in roller derby challenges us to rethink old dichotomies that separate mind and body, 'real' and virtual, feminine and masculine. The 'tough' roller derby 'girl', willing and able to endure pain for the pleasure of the game, has become a powerful figure in contemporary western popular culture. Our analysis of roller derby reveals women's complex relation to pain and pleasure, as part of a feminist reimagining of sport. Through an analysis of derby texts we explore how painful affects are mobilized in particular ways: to imagine collective belonging, to invent alternative feminine subjectivities, and to mark out the limits of self and other. In this way we endeavor to think through the affective experience of derby and how sport might become more gender inclusive as a transformational cultural site. The embodiment of pain is not simply one of 'overcoming', but a corporeal relation that is productive of multiple feminine subjectivities.
\end{abstract}

Key words: affect, sport culture, pain, gender, roller derby, subjectification 


\section{Introduction}

Roller derby has emerged as a women's sport culture that celebrates the pleasurable embodiment and symbolism of pain. Sprains, gashes and bruises mark the gendered sport body in ways that reveal the affective process of subjectification - of becoming 'derby grrrls' - in multiple ways. In this article we explore the deployment of 'pain' in roller derby as an alternative women's sport. If, as articulated by Braidotti, 'the body is a surface of intensities and an affective field in interaction with others' (2011: 25), then the significance of pain becomes central to roller derby cultures and identities. Rather than defining the body by its organs and functions, or defining it by its shape and build, 'instead we will seek to count its affects' (Deleuze and Guattari, 1987: 257). In this article we argue that for the bodies 'sexed as female' in roller derby, painful affects are productive for exploring the complex relations between gender and sport. The exploration of pleasure and pain is suggestive for thinking about women's sporting corporeality beyond the gendered limitations of a mind/body dichotomy that reproduces inferiority in relation to the masculine.

We ask, therefore, 'what can a woman's roller derby body do?' The women involved are not imitating being a roller derby 'girl', nor is there such a thing as a 'natural' derby 'girl', an essential set of qualities for what such a woman is; instead, women are becoming-derby 'grrrls' through the performance of sport. These derby 'grrrls, ${ }^{\mathrm{i}}$ have wide ranging effects and affects on the micro and macro levels of the individual and collective sporting body (derby leagues). Derby bodies can influence debates in feminism, skate faster than most, shape the management of local leagues, injure other players, or be injured, care for others, excite men and women with their bodies, participate in music and art, perform fashion and style, and so on. Roller derby allows the women involved to use their bodies in multiple ways, affecting 
themselves and those around them, enabling alterative subjectivities to be felt and lived in ways previously unimagined. Women have multiple relationships with pain in roller derby and in this article we extend ways of theorizing the gendered relations of pain through sport.

More specifically, we draw upon the growing body of work on affect in cultural studies (for example, Ahmed, 2004b; Gorton, 2007) to explore the affective aspects of subjectification - 'the way a human being turns him- or herself into a subject' (Foucault, 1991: 11)_as a more particular way of thinking about 'becoming derby grrrls'. Through an analysis of pain the active processes of self-formation become visible. We argue that subjectification is 'painful' and that it is through pain that women become subjects via wrestling with gender power relations and the government of self. Braidotti writes,

Change is a painful process, but that is no reason not to engage in it, as the conservatives recommend. The point in stressing the difficulties and pain involved in the quest for transformative politics is rather to underline the dignity of the project and to raise the awareness of the complexities it involves. (2011: 79)

Feminist work in cultural studies has explored the complexity of embodied transformation through everyday practices that shape the self in ways that enable women's capacities, as well as undermine them (for example, Ferreday, 2003; Johnston and Barcan, 2006). We extend this line of inquiry into the transformational body by exploring how roller derby evokes affects, such as pain and pleasure, which mark the becoming feminine subject in particular ways. The physical and cultural demands of roller derby require women to actively 'work on' themselves through the play, performance and competitiveness of sport. In becoming derby grrrls they learn to embrace pain as part of the process of subjectification. 
In sport there is a dominant ('masculine') trajectory of embodied transformation: become fitter, stronger and more competent. The pain of aching muscles, sore joints, strained tendons, bruised skin and mental angst, is something to be overcome. Mental toughness is to be exercised over bodily limitations and vulnerabilities in the normative development of sporting prowess. Pain (and injury) also often signifies the end, or near end, of a sporting career for both professionals and amateurs (Stebbins, 1982). Yet the sport experience, for men and women, is much more complex. Women in sport, particularly those who push themselves and are seen as strong and skillful, are often labeled 'butch' or 'manly' in a derogatory sense (Caudwell, 2003). Research has shown how women in sport often present an emphasized, 'hyper' femininity in order to avoid discrimination and derogatory commentary on their performance (Caudwell, 2003; Lock, 2006). In roller derby women do this to some extent; they signify hyper femininity through adornments such as fishnets and garter belts and allude to other 'feminine' styles such as burlesque and pin up. Yet as well as these cultural signifiers, women in roller derby also mobilize affects, in particular articulations of pain, and the relation between pleasure and pain, to reconfigure femininity and skew the compulsory order of sex/gender.

For women in roller derby there are multiple relations to pain. It is not just something to overcome, but something to take notice of. Pain does not signal an end; it is often a beginning, or a break, or a restart. Pain is something to be proud of and, as Peluso notes, 'bruises and breaks conveys to fellow members one's knowledge of the game, one's skilled or “expert” status, and one’s overall toughness' (Peluso, 2011: 44). Pain is something to avoid, but also sought out in women's desire to win and their desire to become different to what they are. Hence, women's relation to 
pain is cultural, unstable and mobile. In contrast to naturalized discourses of pain arising from sport injury the embodiment of hurt in derby is interpreted through the multiple relations that shape feminized sport culture. We concur with Ahmed's observation of the embodied relations of affect when she states, 'how we respond to objects and others, that surfaces and boundaries are made: the "I" and the "we" are shaped by, and even take the shape of, contact with others' (2004b: 10). Sport contact is anticipated but it is not predetermined, nor can it be ordered and contained in advance to reduce pain. We argue that roller derby is an exemplar of this unstable relation to pain and we explore this through different women's interpretation of pride and shame through their injured bodies.

\section{The Rise of Roller Derby}

Roller derby is a physically demanding, 'risky' sport that in recent years has grown in popularity. An updated version of the 'original' roller derby (Mabe, 2008), today the sport is explicitly 'skater run' and 'democratic' (Beaver, 2012). The largest governing league, the Women's Flat Track Derby Association (WFTDA) based in the US has the following text written into their mission statement: 'The governing philosophy of the WFTDA is "by the skaters, for the skaters." Female skaters are primary owners, managers, and/or operators of each member league and of the association' (Women's Flat Track Derby Association, n.d.). This overt focus on gender and its relations to Do it Yourself (DIY) philosophies (for a detailed discussion see $x, 2012$ ) mean that roller derby is unlike most other mainstream sports. Roller derby is a cultural assemblage where style, belonging and creativity are embodied through physical capacities, teamwork and competition in an eclectic mix of visual art, high-performance training, large-scale events, anti-corporate sentiment, democracy, subculture and music. It is not uncommon to find entire websites devoted 
to derby poetry ${ }^{\text {ii }}$, derby 'fashion, iii, and roller derby crafts ${ }^{\text {iv }}$, as well as more 'official' sites about rules and upcoming events ${ }^{\mathrm{v}}$. These virtual derby communities have grown alongside the hundreds of roller derby leagues around the world since 2001 currently the WFTDA states that there are '900 and counting' leagues worldwide (Women's Flat Track Derby Association, 2011b).

This 'explosion' of roller derby onto the cultural landscape has brought with it a number of questions about female subjectivity, gender and sport. Some of these have been already explored in the academic literature (Beaver, 2012; Carlson, 2010; Cohen, 2008; Donnelly, 2012; Finley, 2010; Peluso, 2011; Storms, 2010). As a challenging sport that has attracted a large number of women who have not previously participated in organized sport, roller derby pushes women in ways they may never have experienced. The strain of competing is compounded by the inherent 'riskiness' of the game - being on roller skates, pushing opposing players out of the way using their shoulders, hips or 'butt', and skating at fast speeds around a tight track ${ }^{\mathrm{vi}}$. Injuries in roller derby are relatively common. Yet, unlike in mainstream sports where injured players are rushed off the field/track quickly, roller derby injuries are collectively celebrated. Players stop on bended knee, the crowd watches and applause follows the injured player. There is an unusual 'pleasure' garnered from pain in roller derby, which has prompted us to ask: How and for what purpose are painful affects 'deployed' in this particular women's sport culture? We aim to contribute a different understanding of the embodiment of derby culture through a focus on affect as an under examined area within the sport and culture literature.

To address these questions we turn to the literature on affect, drawing on poststructural approaches mapped out by writers such as (1996; 2005), Deleuze and Guattari (1987), and Ahmed (2004b). Affects, emotion and feelings have been 
increasingly explored as a way of refiguring the mind/body disconnect. For women in particular the 'splitting' of mind and body has had, and continues to have, dire consequences. Women often reject their bodies, its pains and pleasures, in an attempt to overcome the effects of inequity and subordination. Within the context of advanced liberalism, rationality and control are qualities to be nurtured, while emotionality, irrationality and pain are to be avoided. In roller derby, women embrace and perform their bodily selves. In a paradoxical way, women engage in roller derby as a disciplined practice governed by rules for team sport, hierarchy, and strict membership codes. Yet, roller derby is also mobilized in ways that contest the normative regulation of the body to achieve transformative affects.

Our analysis of painful affects involves a reading of derby texts. Taking our lead from Ahmed, we are interested in making visible 'not just the textuality of emotions, but also the emotionality of texts' (2004a: 27). The 'texts' we have chosen to read are multiple, highlighting the layers of complexity in researching affects. These ‘texts' include public websites and images ${ }^{\text {vii }}$, interview transcripts from women actively involved (or previously involved) in roller derby in Australia, and the first author's auto-ethnographic field notes. By situating our research in these three 'sites'; screens, interview transcripts and researcher field notes; we show the different ways painful affects are mobilized and embodied in roller derby.

In 2010 the first author joined a roller derby league in Australia and for one year experienced the pleasure and pain of the sport (see $\mathrm{xx}$; $\mathrm{xx}$ for more detail on the auto-ethnographic component). These experiences of roller derby were intense, with training held two to three times per week, on top of volunteering to help run the league, engaging in online communication via email, Facebook and roller derby specific forums, competing in bouts, and managing interpersonal relationships with 
other women involved. In joining a roller derby league $\mathrm{X}$ continued to grapple with the implications of doing feminist post-structural ethnography, negotiating the tensions 'between the political imperatives of feminism to make visible women's experiences and the post-structural critiques of representation' (Lather, 2001: 199). Hence the use of multiple methods in analyzing affects; discourse analysis of virtual spaces (Mautner, 2005), discursive analysis of interview transcripts and the incorporation of X's 'experiences' of roller derby, as mediated by her field notes and memory. In this way we do not present texts as sources of interpretive 'truth' but instead consider them as constituting a derby assemblage (Law, 2004). We present fragments, from online sites, interview transcripts, and the first author's autoethnographic writing, as a way of critiquing representation and making women's experiences visible as we use affects to think through roller derby.

\section{Affect and Pain}

Pain is most commonly discussed in biological and psychological terms, and is rarely discussed as a social and cultural analytic except in some research in sport (Singh, 2011; Loland, 2005), disability (Sparkes and Smith, 2008) and sadism and masochism (SM) practices (Newmahr, 2010). Writing about pain is difficult, which speaks to the popularity of Elaine Scarry’s (1985) work written over two decades ago. Scarry's work, about pain's resistance to language and therefore to knowledge, has opened up a range of analytic questions about how to approach the painful body. We have found her work invaluable in thinking through pain in roller derby, yet in this article we attempt to beyond this impasse in an attempt to analyze pain as productive of sport bodies and gendered ways of knowing. 
The journal Pain, with contributors from the disciplines of medicine, psychology and biology, acknowledges the physiological and psychological - and therefore the affective - phenomenon of pain. The International Association for the Study of Pain (IASP) defines pain as: 'an unpleasant sensory and emotional experience, associated with actual or potential tissue-damage or described in terms of such damage' (in Arntz and Claassens, 2004: 20). The inclusion of the term 'unpleasant' is interesting as it highlights the limited ways in which pain is commonly conceived as inherently (biologically) negative. Arntz and Claassens (2004) tested the hypotheses that meaning influences the pain experience and found that in their clinical tests it did. 'When informed that a cold metal bar was hot, participants tended to rate its painfulness as higher than when informed that it was cold' (Arntz and Claassens, 2004: 23), due to the anticipation of tissue damage caused by a hot burn. The IASP's focus on actual or potential tissue damage importantly recognizes the cultural context of pain and we extend this notion to consider how pain is configured in roller derby through 'mediatized' women's bodies where skin is a significant surface. Probyn's work challenges naturalistic assumptions about interiorized meaning ('in the body') by conceptualizing the social world in terms of the relations between 'surfaces', rather than inquire into the 'depths of sociality' (1996: 19). This focus on surfaces moves our analysis of pain away from a sole focus on tissue damage and other biological markers, towards the signifiers, impressions and texts that trouble singular notions of pain in roller derby. Instead of trying to locate pain within the biological body we ask - what does pain do?

Roller derby culture is produced through a fleshy interplay between skins and screens; the immediacy of sweat and the distance of image where women's bodies are constantly negotiating proximity and distance, fantasy and embodied sensuality. In 
virtual spaces women's embodiment is evoked and practiced through multiple relations; pain is not simply associated with normative gender ideals of self-sacrifice (giving birth) or something to be avoided in the desire to preserve femininity (risky sport). Tomkins, arguably one of the most influential theorists of the affective turn, viewed the skin, and in particular the face 'as of the greatest importance in producing the feel of affect' (in Thrift, 2004: 61). In the virtual space of derby websites gendered skin and faces are refracted through screens, images and language that produce an assemblage of affects. Ahmed (2004a: 29) writes of the way surfaces and borders are constituted through the impression others make on us - the emotion and affects, such as pain, that draw us closer or move us away from an object, person, idea. Engagement with others through Internet sites enables different time-space experiences of affect as one gendered body writes, another responds, the intersubjective encounter is created simultaneously and experienced autonomously (Deleuze, 1988). Painful affects are managed and experienced by women in various ways in derby culture. They are inextricably and explicitly linked with notions of community and difference that are vital to the embodiment of collective and individual belonging. In this sense the imagined community of roller derby is 'made up', as are the selves that inhabit it, through an assemblage of visible and explicit painful affects. In terms of these tensions that we ask: what do the affective relations of derby culture reveal about the growing appeal of this sport for women?

\section{The Hall of Pain: Tough or Vulnerable?}

In roller derby there is a desire to legitimate the 'realness' of the sport: Injuries, bruises and pain are over-emphasized to signify that derby should be treated seriously as a 'real' women's sport. Even the organization attempting to govern roller 
derby at an international level has engaged with the question of whether roller derby is 'real', responding in their frequently asked questions section: 'The roller derby of today is real and is thought of as more of a sport than a spectacle...They train hard every week and wear their bruises and scars with pride' (Women's Flat Track Derby Association, 2011a). In roller derby injuries are ritually celebrated with pride. Women who have been hurt either in training or official bouts will take photographs of their injuries and upload these images onto websites or social network sites. In a sense women use the Internet as a way of rewriting their own sense of themselves as feminine as 'a sort of expanding universe to which no limits could be fixed and which would not be incoherence nonetheless' (Irigaray, 1993: 31). Troubling the real/virtual binary, a number of leagues have dedicated sections of their websites devoted to displaying images of their members' injuries ${ }^{1}$. The Rat City Roller's has a section of their website named 'Hall of Pain', where they state,

These are the real injuries incurred at practice and at the bouts of the Rat City Rollergirls. We train hard and we play hard and the occasional injury comes with the territory, just like any other sport. But what better way to help you appreciate all that we go through in the name of derby than the Hall of Pain: a gallery of some of our best (worst?) injuries.

If you're squeamish, you may not want to look. Rat City Rollergirls are the toughest girls around, and we've got the broken bones, split lips, concussions and bruises to prove it. Parents, this section is PG-13 for sure (Rat City Rollers, n.d.).

The images of bruised and broken skin are often accompanied by a smiling 'derby girl', waving her injured arm at the camera, at us. Other images conjure a 'feminine' 'hetero-sexy' (Francombe, 2010) image of pain, with fishnet stocking marks embedded into scraped thighs. These images mark out the 'tough', pain tolerant sport bodies and the affective relations that shape collective identity of the roller derby

\footnotetext{
${ }^{1}$ For example, http://svrollergirls.wordpress.com/tag/hall-of-pain/; http://ratcityrollergirls.com/news-and-photos/hall-of-pain/; http://www.terminalcityrollergirls.com/hallof-pain; http://rollerbootique.com/\#/hall-of-pain/4565531884
} 
community. The pride and pleasure produced through representing pain to others also shapes women's own embodied relation to themselves as ‘tough' and ‘feminine, viii.

Roller derby culture is similar in certain ways to other non-traditional sports (e.g. women’s football) but the affirmation of painful affects creates a gendered space that plays with the limits and possibilities of women's sport bodies. In his ethnography of professional wrestling, Smith (2008) found that non-debilitating pain works as a 'testament to authenticity and realness' for the men involved (141). He states 'that experiences of pain are governed by shared understandings about the meaning of pain that can be categorized as denial, authenticity, solidarity, and dominance' (Smith, 2008: 140, original italics). Like women who play roller derby, professional wrestlers use pain as a way of authenticating their experiences. Smith (2008) notes the tensions between the presentation of pain as 'real', and the need for wrestlers to deny pain - to not be seen as weak or vulnerable. Derby is a site where gendered play invokes embodied vulnerability and strength as women negotiate individual and collective sport affects.

More recently, Green (2011) has explored the way pain serves as the basis for community within the hetero-normative masculine culture that is mixed martial arts. He argues that 'we build intimacy through shared vulnerability and toughness, the two extremes’ (Green, 2011: 390). In mixed martial arts affecting others and being affected is a key part of the attraction of the sport. The ability to affect and capacity to be affected is also central in roller derby. Yet this is gendered in very particular ways. Pain makes visible the women's relations with each other and the sport itself. The recognition and exchange of pain, both corporeal and virtual, is central in roller derby. Pain marks out the sport - as 'real' - and the women who play (often in fishnet stockings and short skirts) as serious contenders. For women however, it is not simply 
a matter of exerting 'mind over matter'. Rather, for the gendered bodies in roller derby, pain expands femininity beyond ideals of service to others (laboring) and selflimiting corporeal schemas.

In roller derby, women risk pain and injury to be part of a team to actively challenge the dominant misconception that they are subordinate and weak. This focus on pain is one of the main elements that separate the contemporary revived version from the roller derby of the past. Scarry (1985: 4) argues that pain is the most 'vibrant example of what it is to have certainty' and that hearing about someone else's pain is the ultimate model of what it is to 'to have doubt'. The imagined pain of derby bodies that circulates in virtual spaces is often commented on by the roller derby community; women empathize, sympathize and celebrate injury and pain. The shared, public experience of pain creates shared affects that connect women with a certainty not necessarily found in other areas of their lives. Physical pain, avoidance and experience of, as well as the exchange of images of injury have become central to the formation of community and a post-feminist identity (McRobbie, 2009) through roller derby.

The centrality of pain (either potential or actual) in roller derby opens up space for the articulation of new theorizations of individual and collective subjectivity that can move beyond normalized notions of authenticity and community. Ahmed writes that 'pain involves the violation or transgression of the border between inside and outside, and it is through this transgression that I feel the border in the first place' (2004b: 27). Questions of identity, both individual and collective are often answered through pain. X's experiences of roller derby speak to the importance of not only experiencing pain, but in many ways enjoying it. She writes,

Last night at training I pulled a muscle in my ankle, but this morning I bought an ankle strap and decided not to worry. When I told a couple of the others 
they told me stories of their injuries and how they didn't tell anyone (in fear of being taken off a team) so I did the same. It was fine! All that worry! We are always so precious about our bodies but I think they are a lot tougher then we give them credit for (Field note, $30^{\text {th }}$ October 2010).

Being injured, but not complaining - and therefore being 'tough' - is important in roller derby. 'Girly' affects, such as sadness, worry, and fear, are very much rejected in roller derby (see also Finley, 2010). Risk-taking in sport is usually constructed as a way of performing dominant masculinities (Collison, 1996 in Young and Dallalre, 2008: 238; Lock, 2006) and shapes individual responses to pain and injury. By performing risky sport identities women trouble the gender expectations that limit their embodied and affective capacities. In doing so they may also struggle to move past the mind body divide and fail to problematize the sex/gender order. The embrace of pain in roller derby may be read as a valuing of masculinity, strength and toughness in the rejection of 'femininity'. However, we argue that such a reading buys into and reproduces gender binaries: Derby produces multiple affective relations where pain and pleasure, self and other, limitations and possibilities are both imagined and felt.

Pain and injury are actually brought onto 'center stage' in roller derby and made visible through websites such as the halls of pain mentioned above, craft books such as Knockdown Knits: 30 Projects from the Roller Derby Track (Carr, 2008) that instruct users on to how to create DIY slings and heat packs, and derby moniker's ${ }^{\mathrm{ix}}$ such as ' $3^{\text {rd }}$ Degree Burns', 'Acute Discomfort', and 'Beautiful Death' ${ }^{\mathrm{x}}$. Bringing pain, both its possibility and actuality, to the fore is quite different from the control and masking of pain that often occurs in masculine dominated sports. Our participants understand themselves as 'tough', but in different ways to men. Kate ${ }^{\mathrm{xi}}$ (28 years) had recently joined her local roller derby league when interviewed, but had previously been training and competing in boxing. In talking about the physical aspects and risk 
of injury in roller derby she stated, 'I think it's a different breed of person that can, I mean, there must be a little bit of insanity in there to want to [play roller derby]'. Another participant, Debbie (37years) who had been playing for over three years also reflected on what was different about 'derby grrrls', stating,

I think you've got to be a certain type, definitely, you've got to have a little fire in the belly, you know there are just certain types that just aren't made up that way...The aggression, as long as there is not bad intent in it, I think it is just a release, a motion that's released basically.

In configuring themselves as 'tough' these women take an alternative orientation towards pain, one that is focused on the movement of affect as 'release' from gendered limits, rather than stasis and stability. As noted by Ahmed 'hardness is not the absence of emotion, but a different emotional orientation towards others' (2004b: 4 original italics). Women in roller derby are 'tough', but they still feel emotions as they encounter their own and others vulnerabilities.

In trying to articulate the aggression and contact in roller derby Tia (39 years), president of her league and a very strong skater, said:

I think you've got to be able to take it to give it. If you're going to play you play hard. You're not out there to get your finger nails done or your hair to look pretty at the end it, because you know, it's for some people and it's not for others. There are some of us that are probably a little rougher than others so I guess it's for the rough people's sport.

Our participants attempt to counter the dominant ways of understanding femininity, using pain to understand themselves as 'different' from other women. The argument we are making here is in contrast to those made by writers such as Rebecca Lock, in her exploration of pain in women's hockey, where she suggests that 'pain is strategically used to produce and maintain an intelligible heterosexual society' (2006: 163). In roller derby women traverse the gay/straight spectrum and use pain as a way of constituting themselves as 'different', 'tough' women. Pain is not something all women seek to avoid, but rather something they move through in the process of 
transforming themselves into 'derby grrrls'. Curiously the tough and vulnerable relation to pain occurs alongside a strong focus on safety within many leagues' policies and procedures.

There are times when the embodiment of pain can become too much to bear; where the limits of self are encountered. For Bianca (26 years), an injury at training where she broke her tailbone highlighted both her vulnerability and desire to be a ‘tough’ derby grrrl.

I was like don't cry, stay really tough. But I drove [my boyfriend] to training and I was sitting there and he said you don't look well and I was like I don't feel well and when we found out the next day... but you can't do anything for it you've just got to ice your bum and put up with it. You're supposed to take a certain amount of time off but I didn't take as long as I was supposed to. I kind of felt from all the emails and everything I was getting that I was missing out and I didn't want to miss out... I felt like I was missing out on bouts and outdoor skates and stuff...(Bianca, 26 years).

For $\mathrm{X}$ as well, her excitement at being able to play in a 'bout' and her negation of her injured ankle challenged her 'toughness' as over the proceeding days and weeks the injury did not fully recover. Falling on her ankle again at training, she went home to try and rest:

I can’t walk! I fell on my injured ankle and now it feels broken. Am hobbling around the house. It is so painful to walk on even though it is strapped tight.

$\mathrm{X}$ had torn a ligament, and this, along with her 'rink rash' left her questioning her newly found 'tough' derby grrrl subjectivity and that of the other women involved.

Experiencing themselves as tough and vulnerable, and experiencing pain and pleasure through roller derby, allow women to challenge assumptions as to what their bodies can (and should) do, and therefore who they understand themselves to be. For example June, a 37-year-old naturopath, spoke of roller derby as a 'duality in my life'. She experienced the sport as 'healing' and as a place where she could put her feelings of anger 'into something positive'. She described her life in terms of emotional pain, 
as 'broken', before she came to roller derby. June did struggle to move past a way of talking about roller derby that did not maintain gender binaries - she went so far as to muse about whether the sport 'brings up testosterone', stating, 'if anything it's a very masculine environment sometimes'. However, she was also able to move towards a different understanding of herself as a woman. Through roller derby she became capable of toughness and vulnerability, hurting and nurturing.

Having broken her leg, and needing subsequent surgery to treat the break, she reflected,

You suddenly feel so fragile and vulnerable and lost...your body shuts down really quick because of the shock...straight away I was like 'crutches, hospital, not working'... when I went down [after breaking my leg] I was screaming because I was thinking all that in just a few seconds. 'No, I just fucked myself!' 'What am I doing?'

But roller derby had created a range of affects in June's life that she could not abandon because of serious injury. She questioned whether to go back, but then said,

But I do love it...I love the community. On my Facebook, I have some beautiful messages from some of the girls. It makes you realize you're part of a community. You start to get really fond of everyone. We've had our dramas, but I think there are some really awesome people who are trying to make it all work a bit better.

June was accepted as both tough and vulnerable in roller derby. Being tough and sometimes aggressive, she had found roller derby to healing. Experiencing a major injury had revealed more about her body's capacities - on the day of her injury she said that she felt a bit "'wobbly... a bit unstable...I should have listened to my instinct but I didn't'. In roller derby, the teleological notion of constant improvement and pushing past pain in order to succeed in sport - a singular goal or purpose (Lüschen, 1990)- was challenged and a different relation to pain was enabled. In this way women's experiences and understandings of themselves, and of the women around them, expanded as they came to account for these affects. 


\section{Hurting vs. nurturing}

Roberta Sassatelli, in her book examining fitness culture in the UK and Italy, states, 'the lithe and energetic body, tight and slim, with its firm and toned-up contours is a powerful icon of contemporary western culture' (Sassatelli, 2010: 1). This assertion is similar to that made by Fiske, where he describes the 'beautiful' sporting body as a 'depoliticized ideological celebration of physical labor in capitalism’ (Fiske, 1989: 98). These beautiful sporting bodies, tight, healthy and slim, are in opposition to the 'excessively strong' body, the 'offensive' body, and the 'dirty' body (Fiske 1989) that were presented in rock ' $n$ ' wrestling in the 1980s and 90s, and that are sometimes evident in roller derby today. Although the roller derby community riles against its wrestling origins (see Barbee and Cohen, 2010), women’s bodies in roller derby traverse the size and aesthetic spectrum, from uniformly dressed to highly adorned and everything in between. Rather than present the 'depoliticized', rationalized, commoditized bodies so often seen in mainstream sport, in roller derby the body is made visible, in all its forms ${ }^{\mathrm{xii}}$. Bodies in roller derby hurt, they hurt others, they are strong and big at times, they sweat and bleed. In contemporary popular culture the female heroine is often fetishized, dressed in leather or other tight fitting clothes, 'these characters are first and foremost images of threatening female sexuality’ (Brown, 2004: 65). Some are dominatrices. Their bodies are dangerous weapons, as are the bodies in roller derby, where they can be used to inflict harm on their opponents. In roller derby, women's arses are weapons, and the bigger the better (Carlson, 2010). Roller skates also pose a significant risk; they are bulky, heavy and are often the cause of injury. 
Elias (2006) argues that sports (and society) are becoming increasingly 'civilized'; where sport is a 'symbolic representation of a non-violent, non-military form of competition between states...that excludes, as far as possible violent actions which can seriously hurt the competitors’ (2006: 7). This is what Dunning has termed the 'sportisation' process (1993: 56) and this is certainly reflected in roller derby. Evidence of increased professionalization, less focus on the sport as 'dangerous', and the emphasis on safety (Beaver, 2012) speak to the ‘sportisation’ of roller derby. Yet we argue that this process is not always linear, and it does not necessarily take into account women's desires. Interviews revealed the ways in which women reclaimed 'uncivilized' language in an ironic gesture to Elias and Dunning and provided a space in which women countered this 'civilizing' discourse. They can admit to finding pleasure in affects and actions that would hurt their competitors or themselves. X had the following exchange with one of the interview participants:

$\mathrm{X}$ : And you don't get hurt very often do you?

Leanne: no. I do hurt a lot of people though

$\mathrm{X}$ : Do you? How does that feel?

Leanne: good

Avoiding pain while at the same time inflicting pain on other people came up several times in the interviews, though most of our participants rejected the view of roller derby as violent. Injuries and pain were more likely to be understood as an unavoidable consequence of playing. However, for those women who claimed to enjoy hurting others, there is very little literature to support an analysis that does not demonize or pathologize their behavior. Clinical psychology presents women who are violent as deviant and as victims of trauma (see for example Babcock et al., 2003), yet this way of thinking about women and violence is inadequate for violence in roller derby. Many of our participants expressed views like the ones below, and yet all these women were employed, many had children, some had university degrees, and all were 
committed to training and playing roller derby several nights per week. They were certainly not 'deviant' and most did not identify as victims.

Clara: I love being able to hit someone hard. I love it when the little girls come by me and I can send them flying... I love that I can hit people! 'Cause there's not many areas at the moment where that's ok. You can't hit anyone... "hitting is bad."

Robin: But because I'm an [ 'A' team player], I'm expected to do the [A team's] training and I think, 'I just wanna smash people, I don't wanna do laps' but you know, that's just me

Debbie: I'm hard and I can do what I got to do

One of our research participants, when asked what she wanted to see the league prioritize in the future, responded with 'I just want to hurt people'. A naïve reading of the sport might interpret this as sadistic intent and paradoxically misogynistic, pitching women against women for the sake of men's entertainment ${ }^{\mathrm{xiii}}$. However, we propose a more complex reading of the dynamics and gendered politics of affect. Through experiencing pain roller derby women are undertaking to remake their world, to exercise bodily force and different capacities if only for while. They exercise power by exceeding the limits of language, through moving in ways that has an a/effect. The transformative power of pushing beyond the limits of self was articulated by a number of women in relation to painful past experiences of gender inequity in their lives, such as this extended response from Beth:

Some personal shit happened, I was sexually assaulted in my teenage years and that had a huge affect on me, it just exacerbated the feelings that I already had about my body, and being a women, and missing my pre-pubescent days when things were less complicated and felt stronger and I felt equal to my male counterparts, whereas a whole bunch of stuff happened in my teenage years around quitting gymnastics that made me feel unequal physically, mentally, well maybe not so much mentally, but physically, which then had an impact on my mental outlook, just really felt the weaker sex and that had a lot of long term affects so I think that's why it took me so long to get back into something, and possibly why seeing something like [the film] 'Million Dollar Baby' was so revolutionary for me, cause I was like 'fuck it, she can do it, I can give it [contact sports] a go. 
As mentioned earlier, one of pain's essential characteristics is its resistance to language (Scarry, 1985), our frequently experienced and expressed inability to represent bodily pain adequately in words. When, in a bout, one of the women breaks a leg or other bone or is otherwise seriously injured the entire stadium goes quiet and all players 'take a knee', stopping the game and kneeling on the track until the player either gets up or is removed. This ritual scene seems is a moment when roller derby draws most women towards each other. We respond strongly to these types of moments when the body exceeds language; when the corporeal experience of pain, vulnerability and pleasure in the body, cannot be captured in words. The dichotomous privileging of men against women, minds against bodies, hard against soft, strength against weakness and so on, is momentarily suspended and a different way of being in the world becomes possible, is immanent. This other way of being a body in the world is not the gendered girlhood Iris Marion Young (1990) writes of when explaining the struggle to mobilize corporeal capacities when throwing like a girl. Nor is there simply an accumulation of bodily capital through sport (Wacquant, 1995), rather the process of becoming-derby grrrl is negotiated through pleasure and pain, pride and vulnerability.

\section{Conclusion}

The ‘tough' roller derby grrrl, willing and able to endure pain for the pleasure of the game, has become a powerful figuration in contemporary western popular culture. In this article we have explored the complex terrain of gendered affects in relation to the rise of roller derby sport culture. Writing about pain and pleasure in roller derby challenges us to rethink old dichotomies that separate mind and body, 
real and virtual, and feminine and masculine. We have argued that the complex relations of pleasure and pain that women articulate through roller derby foregrounds the affective nature of subjectification through sport - the process of becoming a derby grrrl who is tough and vulnerable, forceful and caring. Roller derby renders both pain and pleasure visible and invisible, real and imagined through the virtual and embodied spaces of this particular women's sport culture. Images of injuries and bruises sustained through roller derby are circulated via digital communication technologies to elicit shared affective responses. Pain and injury symbolize a strong sporting female self who overcomes the gendered limits that prohibit aggression, active mobility and a desire for pain, or release. Through an analysis of derby texts we explored how painful affects were mobilized in particular ways; to imagine collective belonging, to invent alternative subjectivities, and to mark out the limits of self and other.

Some may argue that this tough sport simply moves women in subject positions that men have traditionally occupied in the desire to become tough, strong and aggressive. Yet, women experience the process of subjectification in very different ways to men; they bring with them gendered bodies marked by histories of pleasure and pain that limit and contain. Derby creates a legitimate space for troubling and expanding gender norms about affect and embodiment that are governed by ‘civilizing imperatives’ (appearance, fitness, self-responsible management) (Elias \& Kilminster, 2006). In a similar vein to other cultural studies scholars we argue that roller derby as an embodied practice offers a counter narrative to a focus on the normalizing, governable subject (Johnston and Barcan, 2006). The troubling affects of derby culture suggests, 
That the modes of subjectivity and corporeality that they can offer cannot be adequately understood only as the submission of a docile body to a cultural dominant or the production of a 'governable subject. (Rose, 1999 in Johnston and Barcan, 2006: 40)

Pain in roller derby is felt, anticipated, enjoyed, suffered, seen, shared and inflicted. Pain is more than a signifier of community or a membership badge, although this is important. Pain in roller derby is enmeshed with individual and collective change. As noted by Braidotti, change is a painful process, but it is a dignified, necessary one (2011). Transformation is a process being undertaken by women in roller derby and as such we identified the complex affective relations involved.

The teleological notion of sport, of harder, faster, stronger, to the point the body can no longer move (because of age, or injury) is specifically gendered as masculine. For women in roller derby, experiencing (and in some cases inflicting) pain is not only about winning or improving physical skills. It is also about affective community, and, more pointedly, about the limits and possibilities of women's embodied subjectivity. Pain in roller derby is not only something to simply push past in demonstrating the primacy of (masculine) mind over (female) body. Instead sport offers a relation, between toughness and vulnerability, hurting and nurturing, which enables a reimagining of women's corporeality. Through the pleasures and pain of roller derby women transform themselves, and each other, in all sorts of unexpected ways. 


\section{References}

Ahmed S. (2004a) Collective feelings. Theory, Culture \& Society 21: 25.

Ahmed S. (2004b) The cultural politics of emotion, New York: Routledge.

Arntz A and Claassens L. (2004) The meaning of pain influences its experienced intensity. Pain 109: 20-25.

Babcock JC, Miller SA and Siard C. (2003) Toward a typology of abusive women: Differences between partner-only and generally violent women in the use of violence. Psychology of Women Quarterly 27: 153-161.

Barbee J and Cohen A. (2010) Down and Derby, the Insiders Guide to Derby, New York: Skull Press.

Beaver TD. (2012) "By the Skaters, for the Skaters" The DIY Ethos of the Roller Derby Revival. Journal of Sport \& Social Issues: 1-25.

Braidotti R. (2011) Nomadic Subjects, New York: Columbia University Press.

Brown JA. (2004) Gender, sexuality, and toughness: the bad girls of action film and comic books. In: Inness S (ed) Action Chicks: New images of tough women in popular culture. New York: Palgrave Macmillan. New York: Palgrave Macmillan.

Carlson J. (2010) The female significant in all-women's amateur roller derby. Sociology of Sport Journal 27: 428-440.

Carr T. (2008) Knockdown Knits: 30 Projects from the Roller Derby Track, New Jersey Wiley Publishing Inc.

Caudwell J. (2003) Sporting gender: women's footballing bodies as sites/sights for the (re) articulation of sex, gender, and desire. Sociology of Sport Journal 20: 371-386.

Cohen JH. (2008) Sporting-self or Selling Sex: All-Girl Roller Derby in the 21st Century. Women in Sport and Physical Activity Journal 17: 24-33.

Deleuze G and Guattari F. (1987) A thousand plateaus: Capitalism and schizophrenia, Minneapolis: University of Minnesota Press.

Deleuze G. (1988) Foucault, London: Athlone Press

Donnelly MK. (2012) The production of women onlyness: Women's flat track roller derby and women-only home improvement workshops. Open Access Dissertations and Theses. McMaster University

Driscoll C. (1999) Girl Culture, Revenge and Global Capitalism: Cybergirls, Riot Grrls, Spice Girls. Australian Feminist Studies 14: 173-193.

Dunning E. (1993) Sport in the civilising process: aspects of the development of modern sport. In: Dunning E, Maguire J and Pearton R (eds) The Sports Process. A Comparative and Developmental Approach. Champaign: Human Kinetics Publishers, 39-70.

Elias N and Kilminster R. (2006) The Collected Works of Norbert Elias, Dublin: University College Dublin Press.

Ferreday D. (2003) Unspeakable Bodies. International Journal of Cultural Studies 6: 277-295.

Finley NJ. (2010) Skating Femininity: Gender Maneuvering in Women's Roller Derby. Journal of Contemporary Ethnography 39: 359 - 387.

Fiske J. (1989) Understanding popular culture, London: Routledge.

Foucault M. (1991) The Foucault reader: An introduction to Foucault's thought, London: Penguin Books. 
Francombe J. (2010) "I Cheer, You Cheer, We Cheer": Physical Technologies and the Normalized Body. Television \& New Media 11: 350-366.

Gorton K. (2007) Theorizing emotion and affect. Feminist Theory 8: 333.

Green K. (2011) It hurts so it is real: sensing the seduction of mixed martial arts. Social \& Cultural Georgraphy 12: 377 - 396.

Irigaray L. (1993) This Sex Which is Not One, New York: Cornell University Press.

Johnston J and Barcan R. (2006) Subtle transformations Imagining the body in alternative health practices. International Journal of Cultural Studies 9: 2544.

Lather P. (2001) Postbook: Working the ruins of feminist ethnography. Signs 27: 199-227.

Law J. (2004) After method: Mess in social science research, London: Routledge.

Lock R. (2006) Heterosexual femininity. In: Caudwell J (ed) Sport, sexualities and queer/theory. New York: Routledge, 159.

Loland S. (2005) 3 Three approaches to the study of pain in sport. Pain and injury in sport: social and ethical analysis: 49.

Lüschen G. (1990) On theory of science for the sociology of sport: new structuralism, action, intention and practical meaning. International Review for the Sociology of Sport 25: 49-63.

Mabe C. (2008) Roller derby. The history and all-girl revival of the greatest sport on wheels, Denver: Speck Press.

Mautner G. (2005) Time to get wired: Using web-based corpora in critical discourse analysis. Discourse \& Society 16: 809-828.

McRobbie A. (2009) The aftermath of feminism: Gender, culture and social change, London: Sage.

Newmahr S. (2010) Power struggles: Pain and authenticity in SM play. Symbolic Interaction 33: 389-411.

Peluso NM. (2011) "Cruisin' for a bruisin": women's flat track roller derby. In: Bobel C and SKwan S (eds) Embodied Resistance: Challenging the Norms, Breaking the Rules. Tennesse: Vanderbilt University Press, 37-47.

Probyn E. (1996) Outside belongings, London: Routledge.

Probyn E. (2005) Blush, Sydney: University of New South Wales Press.

Rat City Rollers. (n.d.) Hall of Pain. Available at: http://ratcityrollergirls.com/news-and-photos/hall-of-pain/.

Rosenberg J and Garofalo G. (1998) Riot grrrl: Revolutions from within. Signs 23: 809-841.

Sassatelli R. (2010) Fitness Culture: the Gym and the Commercialisation of Discipline and Fun, New York: Palgrave.

Scarry E. (1985) The body in pain: the making and remaking of the world, Oxford: Oxford University Press.

Schilt K. (2004) " Riot Grrrl Is...": The Contestation over Meaning in a Music Scene. In: Bennett A and Peterson RA (eds) Music Scenes: Local, Translocal, and Virtual. Nashville: Vanderbilt University Press, 115-130.

Singh S. (2011) The meaning of pain during the process of embodiment: a case study of trainee modern dancers' experiences of pain. Sport, Education and Society 16: 451-465.

Smith RT. (2008) Pain in the act: The meanings of pain among professional wrestlers. Qualitative Sociology 31: 129-148. 
Sparkes AC and Smith B. (2008) Men, spinal cord injury, memories and the narrative performance of pain. Disability \& Society 23: 679-690.

Stebbins RA. (1982) Serious leisure: A conceptual statement. Pacific Sociological Review: 251-272.

Storms CE. (2010) There's no sorry in roller derby: A feminist examination of the collective identity formation of women in the full contact sport of roller derby. New York Sociologist 3: 68 - 87.

Thrift N. (2004) Intensities of feeling: towards a spatial politics of affect. Geografiska Annaler: Series B, Human Geography 86: 57-78.

Wacquant LJD. (1995) Pugs at work: bodily capital and bodily labour among professional boxers. Body \& Society (SAGE, London, Thousand Oaks, New Delhi) 1: 65-93.

Women's Flat Track Derby Association. (2011a) FAQ: Is roller derby real? . Available at: http://wftda.com/faq/is-roller-derby-real.

Women's Flat Track Derby Association. (2011b) Media Kit. (accessed 24/10/11).

Women's Flat Track Derby Association. (n.d.) Home page. Available at: http://www.wftda.com.

Young A and Dallalre C. (2008) Beware*\#! Sk8 at your own risk: The discourses of young female skateboarders'. In: Atkinson M and Young K (eds) Tribal play: subcultural journeys through sport. Emerald Group Publishing, 235254.

Young IM. (1990) Throwing like a girl and other essays in feminist philosophy and social theory, Oxford: Oxford University Press.

i The term 'grrrl' has been used within third wave feminist movements such as the Riot Grrrl as a way of signifying a different type of femininity Rosenberg J and Garofalo G. (1998) Riot grrrl: Revolutions from within. Signs 23: 809-841, Schilt K. (2004) " Riot Grrrl Is...": The Contestation over Meaning in a Music Scene. In: Bennett A and Peterson RA (eds) Music Scenes: Local, Translocal, and Virtual. Nashville: Vanderbilt University Press, 115-130, Driscoll C. (1999) Girl Culture, Revenge and Global Capitalism: Cybergirls, Riot Grrls, Spice Girls. Australian Feminist Studies 14: 173-193.

ii For example, http://derbyhaiku.blogspot.com/

iii For example, http://www.dolledupderby.com/

iv For example, http://www.facebook.com/pages/Roller-Derby-Crafts-andMerch/166777663368868

v For example, http://www.rollerderbyaustralia.com.au/information/rules/

${ }^{v i}$ A roller derby track is an oval track that fits approximately into the space of a basketball court. This relatively small size means that corners are quite tricky to skate around and require a particular level of skill and strength.

vii Websites used in this article are 'public', not requiring a password or registration to access information.

viii At no point did women interviewed for this research speak about male audience members and what their relation to this audience was. Finley's 2010 
article does discuss this relation to the audience to some extent, but this would definitely be an area for further research.

ix Women in roller derby take on a 'derby name' that they make up for themselves or that is given to them by other women in their league.

x For a complete list of names see http://www.twoevils.org/rollergirls/. Not all names evoke pain or painful affects, but a large proportion does in some way. ${ }^{x i}$ All participants have been given pseudonyms to protect their anonymity and confidentiality.

xii Although there are still a range of body sizes and shapes that participate in roller derby there can be observed a definite trend towards slimmer bodies as the sport grows and competition becomes more serious.

xiii 'Official' statistics regarding the demographics of audience members of roller derby are incomplete, however the Women's Flat Track Derby Association found that $61 \%$ were female and 39\% male (http://wftda.com/sponsors/2012demographic-information) 